\title{
THE USE OF VISUALIZATION WITH PICTURES AND CONCEPT MAPPING TO IMPROVE ENGLISH VOCABULARY MASTERY OF PRE-SCHOOL CHILDREN
}

\author{
Nurul Aryanti ${ }^{1}$, Emzir $^{2}$ \\ State Polytechnic of Sriwijaya ${ }^{1}$ \\ State University of Jakarta ${ }^{2}$ \\ nurulpoltek@yahoo.com \\ emzir.pb@gmail.com
}

\begin{abstract}
Many studies have come to a strong conclusion that pre-school education is important in supporting children to be ready in their future academic and social development. The writer would like to find out if there is an increase in the mastery of the English vocabulary of the pre-school children through visualization with pictures and concept mapping. A combination of qualitative and quantitative study with pre-test and posttest has been conducted to find out if there is an increase in the mastery of the English vocabulary of kindergarten children of Chatya Manis after given materials using the method. 40 children were chosen to be the samples of the study. The study reveals that there is a significant difference between the average value of the test before and after learning model concept mapping activities.
\end{abstract}

\section{Keywords: pre-school education, vocabulary, pictures, concept map}

Pre-school education is vital. According to some experts, it is even the most important education because several studies have shown that past experience in pre-school education gives very large impact on many aspects of a child's development. This early education institution has first developed the potential of affective and cognitive abilities at an early age (Bibi \& Ali, 2012: 153). Bibi and Ali's research result (2012:157) suggests that elementary school children who receive pre-school education tend to have academic achievement and extra -curricular better than those who did not receive pre-school education before.

Problem in the field is the learning materials given to the kindergarten children often do not correspond to the stages of child development. Many kindergartens give kindergarten children lessons of reading, writing, arithmetic and English which are burdensome or difficult for early childhood. Kindergarten is supposed to be a park where children play, socialize and explore turned into early childhood school elementary school that teaches a variety of academic skills. Handling erroneous since the early education will not help children enter higher education level, but it can have the opposite effect. Children are burdened with English subject matter which is abstract or too heavy that they will feel that these lessons are a difficult subject to master.

Most of the teachers of Early Childhood Education (ECD) that teach English do not have the linguistic knowledge and ability to use the English language as well as adequate pedagogical knowledge. The results of the initial survey in early childhood institutions of 
Chatya Manis indicate that the problems facing teachers today are the limitations of the method and the use of instructional equipments at the institution. ECD of Chatya Manis and other sixteen early childhood educations in the District of Ilir Barat 2 still use conventional teaching methods. In the English language learning, the teacher gives an explanation of meaning, definition, translation and speech imitation and interspersed with singing and playing, however the language acquisition is not maximized reached. Bromley (2007:528) says that teaching vocabulary with the teachers' explanation and the use of dictionary definitions excessively does not produce a good understanding or learning.

Chatya Manis kindergarten is part of the ECD of Chatya Manis located at Kelurahan Kemang Manis Ilir Barat 2 Palembang. It has some equipments such as images, flash cards, posters and other props, but in practice the teachers frequently use markers and whiteboard. According to the teachers, the existing props are rarely used. Therefore, the problem of this study is "Is there an increase in the mastery of the English vocabulary of the kindergarten children through visualization with pictures and concept mapping?" The purpose is to find out if there is an increase in the mastery of the English vocabulary of kindergarten children of Chatya Manis after given materials using the method.

Learning English as a Foreign Language to children early childhood development should consider their way of thinking (Chou, 2012). Learning English for kindergarten should begin with an introduction to the vocabulary because vocabulary is the main foundation for the development of language skills and literacy. Linse (2005) suggested that many teachers use a noun in the English language learning early childhood as a noun easily visualized. Most kindergarten students do not have the literacy skills (reading and writing), so that the words are most easily described are nouns. However, language does not only consist of a noun but also a verb, adjective, grammar and so on (Silverman, 2007: 365). McKay (2006) states that children under age 8 will have trouble when taught grammar and discourse.

Determining the vocabulary that will be taught is very important because not all words can be taught to students. McCarten (2007) mentions some of the things we have to consider in teaching vocabulary.

1. Repetition and reinforcement of learned words

Creating an attractive class for kindergarten children is also important in the motivation to learn. To foster motivation to learn, Chou (2012) suggested that teachers pay attention to variations in teaching. Unusual activities with interesting contents and presentation of the varied and charming are one key to successful development of teaching materials. To make the classroom interesting for children, McKay (2006) adds that teachers need to develop activities that keep students actively engaged as they liked physical activities such as moving on and playing.

A teacher should know how the words are remembered and stored in the mind of the learner. Learning vocabulary does not just remember the meaning of words but also how the words are arranged and interrelated with other factors such as experience and background knowledge of the learner. Thornbury (2004: 18-20) mentions that words are processed and stored in the mental lexicon of a complex network in which the words are stored, categorized and related to each other related to the shape of collocation, syntax characters, cultural background and so on. Bromley (2007:531-534) recognizes the complexity of the vocabulary of the English language, such as the many forms of nouns and irregular verbs as well as a lot 
of English words that have double meanings. Nevertheless, the English vocabulary is easier than with other vocabulary such as Chinese, Japanese and Thai.

2. Sustaining Learning Outcomes

Once students learn the material, learning outcomes should be maintained. There are several ways in which learning outcomes can last a long time. Thornbury (2000:24-26) mentions one way to maintain the learning outcomes is by entering information into the learning outcomes of long-term memory through repetition in the use of the word is learned. Bromley ( 2007:531-534 ) suggested that students be given the opportunity to associate new words with other words that are already known and use these words over and over again on various occasions naturally. Given a new word can also be done by the mnemonic is associate abstract words or concepts with other words more meaningful.

3. Use of Images

The next step is maintaining the learning outcomes visualize an image to a new words learned. This method can be combined with graphic organizers or concept maps which are believed to help students keep the memory of the words longer. With the picture superiority not only helps trigger the participation of students but also clarify the information to be conveyed (Uematsu, 2012:49). Pictures can help bring context, meaning, and certain messages and increase the learners' interest on language learning (Wright, 1984).Learners should receive inputs about stimuli and learned the language as much as possible. The teachers need to use a variety of ways that varied by using different images combined with other activities.

Images can be combined with a variety of games that can make students actively engaged. One example is a guessing game. Teachers put a picture on the board 10 and the names of the animals were then followed some simple explanations about the animals. Once finished with his explanation, the teacher repeated the explanation of these animals without naming the animals. The teacher then asks the students to guess the race taking pictures of animals that teachers mentioned characteristics.

Nevertheless, the image has a weakness in conveying abstract concepts or meanings such as opinions or impact (impact). In this case, the image serves as a complement to other learning tools (McCarthy 1992: 115; Thornbury 2004: 81). Based on this, the writer believes that the combination of the use of images and concept maps can maximize the results of early childhood learning vocabulary.

4. Use of Concept Maps

Graphic Organizer (GO) is visualization with diagrams or symbols arranged in a sequence, so that GO can show the relationship between facts, concepts or ideas. GO is also used to describe all learning visualization tools such as concept maps (concept map), a map of the mind (mind map), and diagrams. GO assist the learning process through the use of arrows and a line spacing of text that describes the content, structure, and relationships key concepts (Darch \& Eaves, 1986:310). GO has a wide variety of forms. Carlson and Larralde (1995:157) argue that the concept of Concept Map, which is one form of GO. They say that concept map helps students see the ideas more concrete than abstract words and concept map can show the relationship between ideas and details of information within a text, making for the better understanding. With careful attention to concept map students can explore basic ideas are meaningful and more accurate. 


\section{METHOD}

This is a qualitative and quantitative study with pretest conducted to determine the initial conditions and the posttest to determine the application of visualization of pictures and concept map learning outcomes.

3. Population and Samples

The population and samples are 40 children of Chatya Manis Kindergarten. There are several reasons for the selection of Chatya Manis kindergarten. It is chosen because it has been a pilot kindergarten in the district of Ilir Barat 2, Palembang. Furthermore, the teachers have never implemented concept maps. Although it has some learning aids, they have been rarely used.

\section{Procedures}

Visualization methods were applied using teaching aids and instructional materials in the form of students' work sheets. The tools that were made include the pictures on flash cards, posters, and students' worksheets.

Images combined with a wide range of games that can make students actively engaged. One example is a guessing game. Teachers put a picture on the board 10 and the names of the animals are then followed some simple explanations about the animals. When the teacher finished with her explanation, the teacher repeated the explanation of these animals without naming the animals. The teacher then asks the students to guess the race taking pictures of animals that teachers mentioned characteristics.

Image shaped large posters used to the concept that a lot of detail or complex. Their large size posters are easily seen by all students.

Nevertheless, the image has a weakness in conveying abstract concepts or meanings such as opinions or impact (impact). In this case, the image serves as a complement to other learning tools (McCarthy 1992: 115; Thornbury 2004:81). Based on this, the teachers integrate the use of images and concept maps vocabulary to maximize learning outcomes.

Here is an example of the use of concept map initial step in kindergarten. Teachers prepare a set of drawings of animals and fruit in their names a number between 6 and 8 words conceptually related and familiar to students, for example: frog, cat, fish, monkey, rabbit, carrot, banana and mosquito. Teachers also prepared the framework map flannel board that the image can be attached. Next, the teacher asks the students to connect concepts in images and words by attaching two pictures on the flannel interrelated as the following example (the teacher asks students to choose some animals and the animal food craze and match them).

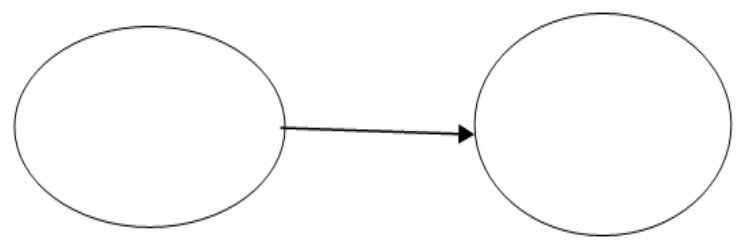

Figure 1. Map Framework 


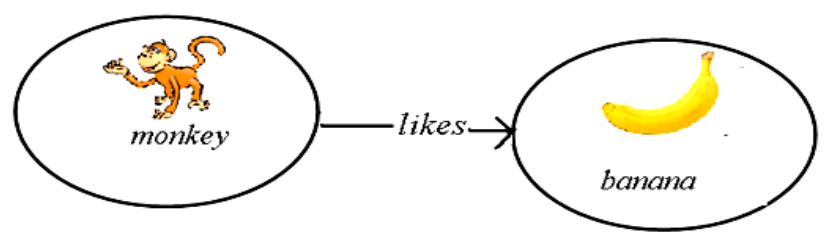

Figure 2. Examples of Simple Concept Map

Teachers should provide a model of the use of concept map. Before the teacher starts teaching preparing materials and tools required. Image attached to a sheet of heavy paper or cardboard circle diameter of $8 \mathrm{~cm}$ and the words (concepts) which will students learn written below the image. Map frame on poster board where students will compose words or concepts are also prepared framework. Before the students work, the teacher gave an example by attaching a poster-sized sample images on the whiteboard that shows various examples of concept maps are already complete. The teacher shows how the various words or concepts in the concept map are interconnected. After completion of the explanation, the students try it by themselves.

The following example shows a sequence concept maps relatively more difficult for children than previous concept map (Figure 12).

These pictures show you that you have to wash your hands before eating. Arrange the pictures based on a correct sequence by putting the pictures into the following skeleton map. (The following picture shows that you have to wash your hands before eating)

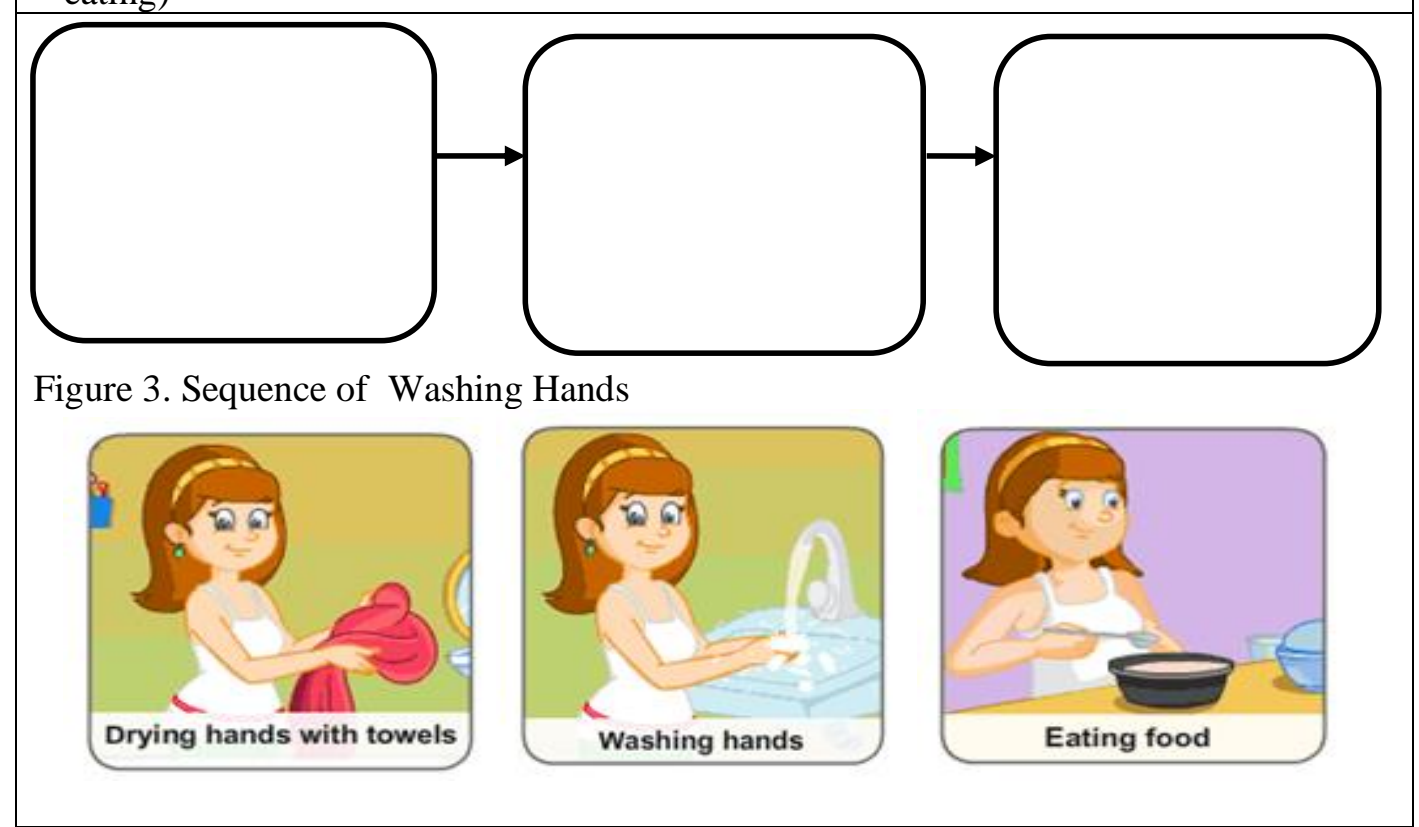

Figure 4. Sequence of Washing hands

After students practiced using the concept map, they got used to the concept map and PK teachers began to give a more complex learning such as the example in Figure 13 (before) 
and picture 14 (after equipped student). Teachers prepared a list of concepts (vocabulary learned) in the field of paper provided by the so-called "parking lot" before compiled into concept map. Teachers trained to use map-making framework blank OD (Skeleton Maps) before they make it by themselves. Then, the students fill the empty frame into a complete concept map (Figure 9).

Concept-making process started from the basic idea of the spread out and makes some branches like a tree root. Students write the title of the discussion at the central point of the paper and made several circles around it. Some circle around the title of a subtitle contains supporting information in the form of facts constructed in stages (Serrat, 2009).

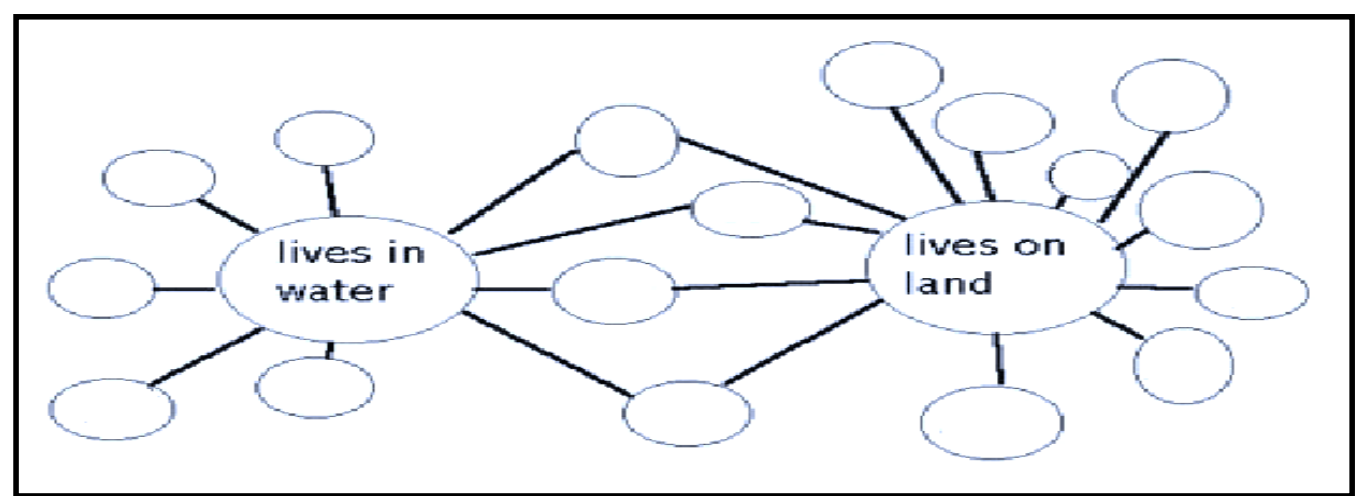

Figure 5. Map Framework

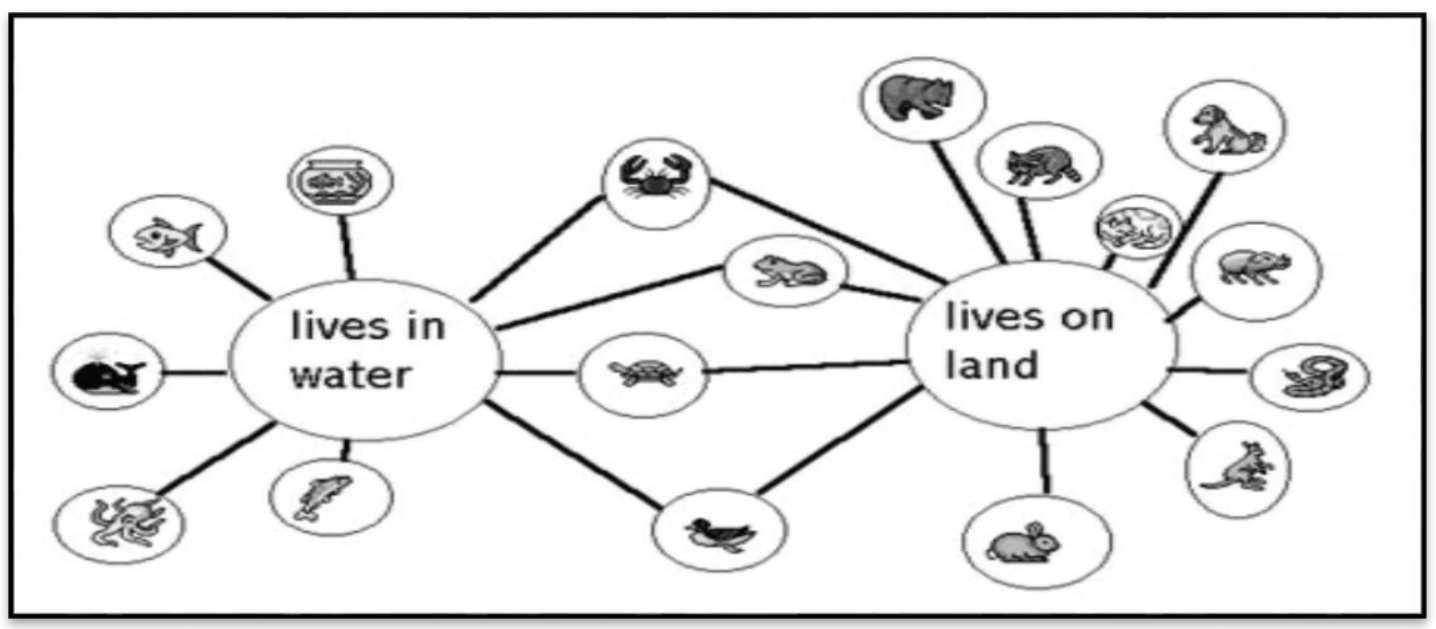

Figure 6. Example of Complex Concept Map

Animal Land and Sea (Accessed May 3, 2013 from http://www.mdianeharrison.com/images/DblBbl.jpg)

From the discussion of the application of these methods, it can be concluded that teachers should make learning becomes interesting and meaningful. To achieve this, the teacher should consider the following: the suitability of topics with the interests of children, stories, games are fun and make a lot of students moving, paired and group activities, the use of images and concept map and varied delivery techniques. 


\section{RESULTS AND DISCUSSION}

In the following discussion, the writer starts from the information about the characters of the teachers and students. The following are some of the characteristics of early childhood teachers who were observed:

1. Patient and friendly, so learning is fun, do not be stingy to give praise and appreciation when the kids doing a good job

2. High-spirited student interest in growing and maintaining a sense of pleasure to compensate those who have high physical activity and easily bored

3. Using simple language

Observation results also show some characteristics of early childhood students observed. Children love games and songs that make them more motivated to be more active and freer in using the English language is learned. Sometimes comes from their English versions. They are active learners who enjoy learning something as well learn while doing something (learning by doing), such as playing games or singing while moving the limbs to imitate something, gesturing or give meaning to the words spoken.

Students are easily bored and short attention and concentration. To overcome teachers provide learning activities they liked and highly varied. When they started to look bored, activities replaced every 10-15 minutes. Before starting to teach the teacher has prepared several variations of techniques in teaching. Some variations were developed from several existing techniques. In the implementation of teachers adjust to the needs and conditions.

The material has been selected according to their interests. They liked the subject matter related to their daily lives and surroundings, for example topics using words or phrases, they also give more attention to the words or phrases relating to the objects of his or worn even in his limbs .

For young learners, they have trouble distinguishing things that are concrete and the abstract. The dividing line between the real world and the world of imagination is not yet clear to them. They have not been able to discern something is real or not real. Relatively simple concrete objects can be introduced to students in English.

In general, sing and listen to a song preferred by almost all children, including the quiet or shy children. They can master the vocabulary and phrases are sung over and over in a fun way and in a short time. Kids can quickly memorize the song of a simple, agile, and easy to pronounce, followed by appropriate motion content of the song.

Furthermore, teachers also use the substitution technique by eliminating one part of a sentence and the students are asked to replace with other similar words. The tools used are flashcards or posters.

Concept maps as a visualization tool is made by asking students to make groupings or activities connecting concepts through images, objects of physical forms and symbols. Given the purpose of teaching is to give students the understanding and importance of conceptual knowledge, teachers need techniques that can assist students in understanding the shapes / patterns and relationships (over memorization in general) and form a mental structure that is expected to assist students in understanding the new knowledge and relate it with the knowledge that has been acquired long (Erikson, 2002). When the net/web graphically shows ideas that relate to the topic, the general concept map illustrates the various relationships that exist between the information. In the method of nets, topic or concept being studied is usually found in the paper circle in the middle, surrounded by the ideas, questions, 
or words, and always relate to one another. The use of aids such as pictures and concept map by Chatya Manis Kindergarten only reached $70 \%$. According to the teachers, some tools rather inconvenient when used because it consists of a lot of cards that must be compiled and concepts as student elusive family tree. In terms of the use of teaching aids, use of blackboard still dominates.

The main activities of the teachers are to facilitate student learning. During the learning process, teachers were able to convey the material with confidence/no doubt, provide more time for students as well as the activity of using the method/approach appropriately and varied.

Interaction with students performed well. The teacher asks a responsibility to find a link concept. Teachers discuss with students to apply a concept both groups and individuals, among others, the task of teachers in applying the concepts and involve the students to test the material has been studied by combining concepts or simple words. Teachers can use questioning techniques (sentence effective questions; given sufficient time to respond and provide an opportunity for every student to ask; respond to student answers). Furthermore, each student teacher to answer questions (giving information with examples; using an effective sentence).

The teacher members of repetition and reinforcement words/concepts learned. Students hear and imitate on spelling. In this technique, the teacher pronounces words in English and students just listen. Then the teacher gave the example again and students are asked to repeat the words of teachers.

It can be concluded that all students are active. The activity of the teacher has been facilitating learners to gain meaningful experience in achieving basic competency. The results of observations conducted feasibility program six times at random showed feasibility of $91.66 \%$. In general, these results can be categorized as excellent.

Pretest results showed that students' mastery of the English language is still very minimal. Some 40 students on average students can only mention two or three names of things, fruits or animals among 46 images shown on the pretest. Previous early childhood teachers Sweet Chatya provided information to the executive team that their students had learned English through song and textbooks. There are various factors that cause students are not proficient in English lessons taught by the teacher. Given limited teaching in the form of songs and read the textbook explanation that accompanied the teacher.

Pretest was given in the form of oral tests conducted by two examiners. Pretest results form the basis of the value of vocabulary in English as a baseline. Pretest results indicate students' vocabulary mastery is still very low. At the end of the instruction, posttest will be given on the pretest with the same test materials. The purpose of the test is to see the achievements of the teaching process by looking at the comparison of the results of pretest and posttest assessment scores. Pretest mean value is equal to 5.7261 while the mean posttest score was 9.8216 .

Table 1

Paired Samples Statistics

\begin{tabular}{|ll|l|l|l|l|}
\hline & & Mean & $\mathrm{N}$ & Std. Deviation & Std. Error Mean \\
\hline Pair 1 & VAR00001 & 5.7261 & 40 & 2.41975 & .38260 \\
& VAR00002 & 9.8216 & 40 & 8.10038 & 1.28078 \\
\hline
\end{tabular}


Mean N Std . Std deviation . Error Mean

Pair 15.7261402 .41975 .38260 Var00001

Var00002 9.8216408.10038 1.28078

Table 2

Paired Samples Correlations

\begin{tabular}{|c|c|c|c|c|}
\hline & & $\mathrm{N}$ & Correlation & Sig. \\
\hline Pair 1 & $\begin{array}{ll}\text { VAR00001 } & \& \\
\text { VAR00002 }\end{array}$ & 40 & .382 & .015 \\
\hline
\end{tabular}

N Correlation Sig.

Pair 1 Var00001 \& Var00002 40.382 .015

Table 3

Paired Samples Test

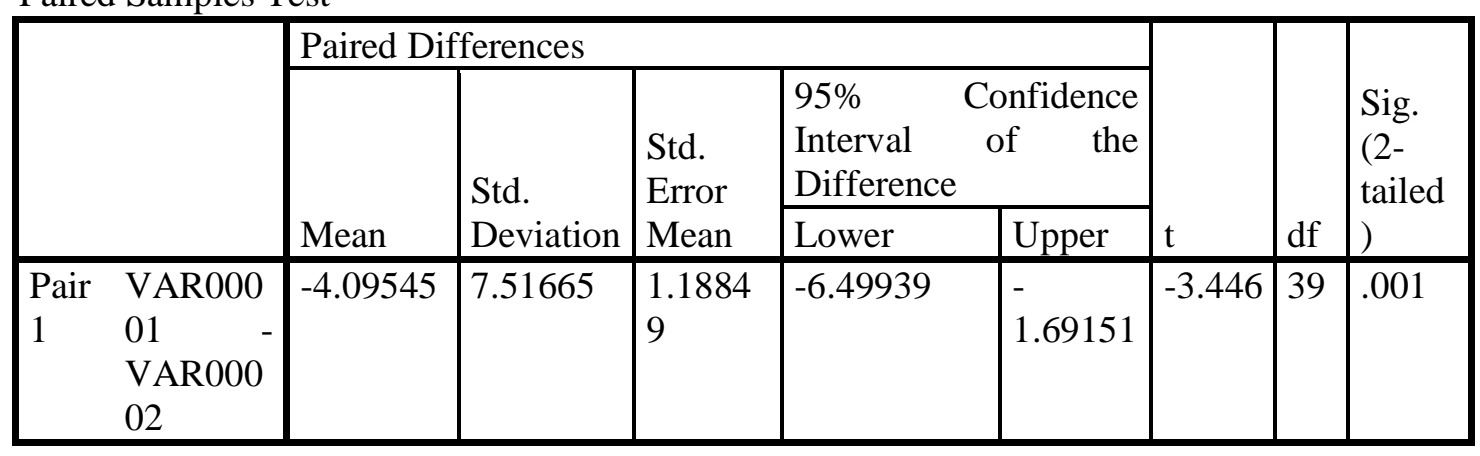

Paired Differences t df Sig. (2 - tailed)

Mean Std. Std deviation. Error Mean $95 \%$ Confidence Interval of the Difference

Lower Upper

Pair 1 Var00001 - Var00002 -4.09545 7.51665 1.18849 -6.49939-1.69151 -3,446 39.001

With df value by 39 we see the Table value "t". It was found that the price of criticism t table at significance level of $5 \%$ by 2:02 while the $1 \%$ significance level of 2.71 . $\mathrm{T}$ seen that the value obtained for 3446 is greater than the value of "t" table at significance level: of $5 \%$ by 2:02: while the $1 \%$ significance level of 2.71. It can be concluded that there is a significant difference between the average value of the test before and after given concept map activities.

There are several factors suspected to be the cause of the increase in test scores in the post test. Vocabulary before application of learning models is very low, PK presents a great opportunity to increase after the application of the learning model. Wash back or influence of the test can also give effect to the posttest results. Other activities such as singing and the use of English outside the formal structured activities such as greeting and simply communicate outside the classroom can contribute to the improvement of students' vocabulary. The topics of My Body, My Family and Me, Clothes and Plants are difficult topics mastered by the student. While the topic of Animals, Fruits, Food and Colors are relatively easily mastered by the student. 


\section{CONCLUSIONS}

Concept map is one of the effective ways to help students show what they know and understand in a visual form. The result of pretest and posttest scores showed significant quantitative differences in the average value of the test before and after training. Improved test scores are statistically significant may be due to their possession before the application of the method is so low that provides great opportunities to increase after the implementation of the method. Aids / instructional media have been used by teachers of Chatya Manis correctly but the frequency of its use is still lacking. Moreover, the writer argues that the application of concept map needs to be expanded and intensified use.

\section{REFERENCES}

Baleghizadeh,S. \& Ashoori, A. (2011). The Impact of Two Instructional Techniques on EFL Learners' Vocabulary Knowledge: Flash Cards versus Word Lists. MEXTESOL,35(2),1-9. $\quad$ Diakses 3 Mei 2013 dari http://mextesol.net/journal/public/files/d8449b5efc1a65123512b9a73b780140.pdf

Beck, I., M. McKeown, \& L. Kucan. (2002). Bringing words to life: Robust vocabulary instruction. New York: Guilford.

Bibi,W \& Ali, A. (2012).The Impact of Pre-school Education on the Academic Achievements of Primary School Students. The Dialogue, 7, (2), 152-159. Diakses 3 Mei $2013 \quad$ dari http://www.qurtuba.edu.pk/thedialogue/The\%20Dialogue/7_2/Dialogue_April_Jun e2012_152-159.pdf

Birbili, M. (2006). Mapping Knowledge: Concept Maps in Early Childhood Education. Early Childhood Research \& Practice,8 (2), 1-10. Diakses 5 Mei 2013 dari http://ecrp.uiuc.edu/v8n2/birbili.html

Bromley, K. (2007). Nine things every teacher should know about words and vocabulary instruction. Journal of Adolescent \& Adult Literacy, 50 (7), 528-537. Diakses 3 Mei $2013 \quad$ dari http://www.johnsoncreek.k12.wi.us/faculty/mentings/Vocabulary\%20JAAL.pdf

Cameron, L. (2001). Teaching Languages to Young Learners. Cambridge University Press. Diakses $\quad 5 \quad$ Mei $2013 \quad$ dari http://assets.cambridge.org/97805217/74345/frontmatter/9780521774345_frontmatt er.pdf

Carlson, P. A., \& Larralde, V. (1995) Combining concept mapping and adaptive advice to teach reading comprehension. Journal of Universal Computer Science,1(3),156-161, Diakses 29 Desember 2011, dari http://www.google.co.id/url?sa=t\&rct=j\&q=armstrong\%20concept\%20map\&source= web\&cd=10\&ved=0CGUQFjAJ\&url=http $\% 3 \mathrm{~A} \% 2 \mathrm{~F} \% 2 \mathrm{Fwww} . j u c s . o r g \% 2 F j u c s \_1 \_3$ \%2Fcombining_concept_mapping_and\%2FCarlson_P.pdf\&ei=TBr9TtDcOoyqrAeC 2LXXDw\&usg=AFQjCNEo-S9-zWIOZkwIbYQnLAD_dasMDA\&cad=rja

Chou, M. (2012). Assessing English vocabulary and enhancing young English as a Foreign Language (EFL) learners' motivation through games, songs, and stories, Education 3-13: International Journal of Primary, Elementary and Early Years Education. Diakses 3 Mei 2013 dari http://dx.doi.org/10.1080/03004279.2012.680899

Christ, T., \& X.C. Wang. (2010). Bridging the Vocabulary Gap: What the Research Tells Us about Vocabulary Instruction in Early Childhood.” Young Children 65(4), 84-91. 
Christ, T., \& X.C. Wang. (2012). Supporting Preschoolers' Vocabulary Learning Using a Decision-Making Model to Select Appropriate Words and Methods.Young Children, 67(2),74-80.

Darch, C., \& Eaves, R. (1986). Visual displays to increase comprehension of high school learning-disabled students. The Journal of Special Education, 20,309-318.

Gairns, R \& Redman, S. (1992). Working with Words: A guide to teaching and learning vocabulary. Cambridge: Cambridge University Press,

Hill, D.A., (1990). Visual Impact: Creative language learning through pictures. Essex: Longman Group UK Limited

Hyerle, D.N. (2004). Thinking maps as a transformational language for learning. In Student Successes with Thinking Maps:School-Based Research, Results, and Models for Achievement Using Visual Tools, eds. D.N. Hyerle, L. Alper, \& S. Curtis, 1-16. Thousand Oaks, CA: Corwin Press.

Irianto, A. (2006). Statistik: Konsep Dasar \& Aplikasinya. Jakarta: Kencana.

King, K and Mackey, A. (2007). The bilingual Edge. Why, When, and How to Teach Your Child a Second Language. New York: HarperCollins Publishers Inc. http://www.harpercollinsebooks.com.

Kloos, K., Baker, H, Luken,E. Brown, R., Pfeiffer, D \& Carr, V.(2012). Preschoolers Learning Science: Myth or Reality? In Current Topics in Children's Learning and Cognition. Working Paper (chap. 3). Diakses 3 Mei 2013 dari http://dx.doi.org/10.5772/54119

Linse, T. C. (2005). Practical English Language Teaching: Young Learners. McGraw Hill: NY

McCarten, J. (2007). Teaching Vocabulary.Lessons from the Corpus Lessons for the Classroom Cambridge: Cambridge University Press

McCarthy, M. (1992). Vocabulary. Oxford: Oxford University Press.

McKay, P. (2006). Assessing young language learners. Cambridge: Cambridge University Press.

Marulis, L.M., \& Neuman, S.B. (2010). Review of Educational Research, 80(3), 300-335. Diakses 3 Mei 2013 dari http://rer.aera.net

Novak, J. D., (1998). Learning, creating and using knowledge: Copncept maps as facilitative tools in schools and corporations. Mahwah, NJ: Erlbaum.

Novak, J. D., \& Cañas, A. J. (2008). The Theory Underlying Concept Maps and How to Construct and Use Them, Technical Report IHMC CmapTools 2006-01 Rev 012008, Florida Institute for Human and Machine Cognition, Diakses 7 Agustus 2011 dari ResearchPapers/TheoryUnderlyingConceptMaps.pdf

Palvio, A. (1991). Dual coding theory: Retrospective and current status, Canadian Journal of Psychology, 45(3), 255-287.

Serrat, O. (April 2009). Drawing Mind Maps. Knowledge Solutions. Diakses 29 Desember 2011, dari www.adb.org/.../drawing-mind-maps.pdf

Shin, S.J. (2010). Teaching English Language Learners: Recommendations for Early Childhood Educators. Dimensions Of Early Childhood ,38(2),13-21.

Silverman, R.D. (2007). Vocabulary Development of English-Language and English-Only Learners in Kindergarten. The Elementary School Journal, 107(4),365-383

Thornbury, Scott. (2004). How to Teach Vocabulary. Essex: Pearson Education Limited. 
Truro Central School, School Committee Policy. (n.d). Preschool/kındergarten assessment plan. Diakses $\quad 5 \quad$ Maret $2013 \quad$ dari http://www.truromass.org/pdfs/PKAssessment\%20Plan.pdf

Uematsu, H. (2012). The Use of Pictures and Illustrations in Teaching English. $21^{s t}$ Education Forum, 7, 45-50. Diakses 5 Maret 2013 dari http://cgi1 .adobe.com/special/acrobat/pluginfinder/pluginfinder.cgi?type=LangPkg \&name $=$ Japn\&os $=$ Win \&

Wright, A.(1984). 1000+ Pictures for Teachers to Copy. Essex: Pearson Education Limited. 